\title{
Paideusis
}

\section{Relevance of Asian Philosophy to Philosophy of Education Today: An Interview with Roger Ames}

\section{Heesoon Bai and Roger T. Ames}

Volume 19, Number 1, 2010

URI: https://id.erudit.org/iderudit/1072326ar

DOI: https://doi.org/10.7202/1072326ar

See table of contents

Publisher(s)

Canadian Philosophy of Education Society

ISSN

0838-4517 (print)

1916-0348 (digital)

Explore this journal

Cite this document

Bai, H. \& Ames, R. (2010). Relevance of Asian Philosophy to Philosophy of Education Today: An Interview with Roger Ames. Paideusis, 19(1), 77-80. https://doi.org/10.7202/1072326ar
Article abstract

Professor Roger T. Ames is Professor in the Department of Philosophy at the University of Hawai $i$, Manoa. The following is a short excerpt from an interview with Professor Ames that took place on the eve of 2009 PESA Conference, December 1, 2009. Heesoon Bai, Editor of Paideusis, accompanied by Avraham Cohen, interviewed Professor Ames in his office.
(C) Heesoon Bai, Roger T. Ames, 2010

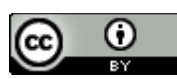

This document is protected by copyright law. Use of the services of Erudit (including reproduction) is subject to its terms and conditions, which can be viewed online.

https://apropos.erudit.org/en/users/policy-on-use/ 


\title{
Relevance of Asian Philosophy to Philosophy of Education Today: An Interview with Roger Ames
}

\author{
Professor Roger T. Ames is Professor in the Department of Philosophy at the University of Hawaici at \\ Mãnoa. The following is a short excerpt from an interview with Professor Ames that took place on the eve \\ of 2009 PESA Conference, December 1, 2009. Heesoon Bai, Editor of Paideusis, accompanied by \\ Avraham Cohen, interviewed Professor Ames in his office.
}

Heesoon Bai (BAI): Hello, Professor Ames. We are very glad to meet you in person today. I have read many of your works, and hoped to meet you some day. As you may know, my field is Philosophy of Education.

Roger T. Ames (AMES): I, too, am in philosophy of education in the sense that Confucian philosophy is basically a philosophy of education.

BAI: (laughter) Excellent!

AMES: One of the controversies that has animated the major academic institutions in China over the last decade or two has been what they call hefaxing 合法性, the "legitimacy" of Chinese philosophy. The question is: "Is Chinese philosophy really 'philosophy'?" My reflection on this issue is influenced in some ways by Pierre Hadot, the distinguished classical scholar. He is for me a negative example in some ways. Basically, this is the story of the Western philosophical narrative as I understand it. The first application of the term "philosopher" was by Herodotus in describing Pythagoras. Pythagoras was certainly the "mathematics guy" - in school we all did the "triangle'. ${ }^{1}$ But Pythagoras was also a religious leader, a social and political activist; he was a musician; he was somebody hugely interested in hygiene and food. Actually, Pythagoras was the first person known to talk about the immortal soul. He was really a person of many aspects, and so the word 'philosophia' - "lover of wisdom"- to describe Pythagoras was entirely appropriate. But what happened in the Western philosophical narrative is that, after Pythagoras, you have the kind of philosophical and spiritual ascent that left the real world behind. With Plato, and then again with Aristotle, you had a kind of elevation of the abstract as being the ideal, while ordinary human experience, ordinary human life, was left behind. The ordinary world was relegated to the "down side," the "south side," of a kind of dualism. For Plato, the ideal is what is most real, and for Aristotle the highest kind of knowledge is intellectual virtue, theoria. Then you have the melding of Christianity with the classical Greek tradition. And so with the Church fathers, not only the theoretical, but also the spiritual, became really emphasized as the ultimate source of apodictic truth and knowledge. All this goes back to Plato and Aristotle. And so what took the place of philosophia in our narrative was a kind of philo-episteme in which a concern for wisdom gave way to the quest for knowledge and truth. Even in our Western philosophy curriculum today, we don't teach 'sophiology' but we do teach epistemology. If I went to the Chair of my department and I said "Jane, y'know, I would like

${ }^{1}$ The reference here is to the Pythagorean Theorem.

(C) Copyright 2010. The authors, Roger T. Ames and Heesoon Bai, assign to Paideusis the right of first publication and educational and non-profit institutions a non-exclusive license to use this document for personal use and in courses of instruction provided that the article is used in full and this copyright statement is reproduced. Any other usage is probibited without the express permission of the authors. 
to teach a course in . . .um ... wisdom, she would say 'Oh, don't embarrass us ... go to the Religious Studies Department if you must, but we in Philosophy don't teach wisdom. Wisdom is not a desired 'student learning outcome' in our philosophy program. We teach students how to acquire knowledge and how to pursue truth'." So Western philosophy in some ways left the track of philo-sophia.

What has happened with Asian philosophies-that would include China, Japan, Korea, and Vietnam-was that from the very beginning they have insisted that philosophy begins from personal cultivation as the ultimate source of meaning. You cultivate your self, you cultivate the family, you cultivate the country, and you cultivate the cosmos. These Asian traditions such as Confucianism, Daoism, and Buddhism were inclusive syncretic traditions-not exclusive traditions--that continually cross-fertilized among themselves and appropriated from whatever would compete with them. For instance, if you take the Four Books ${ }^{2}$ as being the canonical core of the Confucian tradition, and you then add to these documents the counter culture Daoist texts and the Buddhist literature, you then have sanjiaoweiyi 三教為一: "the three teachings as one." So, if you ever lose sight of the core philosophy of personal cultivation and, for instance, you make Zhu Xi into a metaphysician, then you also lose sight of the fact that all of these philosophers right down into the twentieth century are really pursuing a transformation of the ordinary human experience. In Chinese you'd say philosophy is 人間—a philosophy that lives in the lives of the people. You know, it is a kind of philosophy that belongs to the everyday. The whole project is to make the ordinary extraordinary through personal cultivation, and by extension, to enchant the everyday by creating flourishing families and communities. And that cultivation is what we call education. It is as simple as that.

BAI: The first time I was introduced to this idea of philosophy as a wisdom tradition in the West, and as being concerned with personal cultivation, was through reading the work of Pierre Hadot.

AMES: A lot of people who do Asian philosophy have come to celebrate Hadot because Hadot directs his criticism at the professionalization of Western philosophy. Hadot insists that Aristotle and Plato and all of the early Greek thinkers, such as the Epicurians and Stoics and so on, were devoted to what he calls "spiritual exercises." He says these philosophers were really cultivating themselves, and it was probably only with the scholastics in the medieval period wherein the commentary on Aristotle became the work of philosophy and fundamental to university culture that the idea of spiritual exercises was left behind. Hadot complains that what we do in modern professional philosophy is we treat the classical philosophers as though they were doing the same kind of thing that analytical philosophers-the technical philosophers of our own day-are doing; that is, trying to find demonstrable truth. I endorse Hadot's indictment of contemporary Western philosophy. What I wouldn't allow for is the eliding of what Hadot is calling spiritual exercises and what Confucian philosophy is about. For Hadot the philosophical life is a special life. It is a life where you leave the mundane behind, and you dwell in the marble temple on the hill-what William James derides as a kind of reified philosophy that has nothing to do with real human experience. Whatever it was that Plato and Aristotle were advocating is not the same thing as what was being recommended by the Confucians, the Daoists, and so on. What was recommended by the latter has to do with, first, understanding that we are relationally constituted people, and second, understanding that the way that we consummate ourselves as human beings is by living in those relationships in the most meaningful way. But that's not what Hadot was talking about. Probably the best model that reveals what Hadot was talking about is the philosophical ascent described in the Phaedo. This Phaedo is all about this kind of disembodied soul getting in touch with absolute principles in the ideal realm of forms, and leaving not only the world but other people behind.

2 The Four Books refers to the basic teachings of the later Confucian tradition, and consists of: The Great Learning; The Analects; The Mencius; and Maintaining Perfect Harmony. 
This understanding of the human soul is not constituted by its relations; on the contrary, it is an individual soul liberated from those relationships.

BAI: So your understanding is that the early Greeks, before Plato and Aristotle, didn't entertain this kind of transcendentalism?

AMES: That's right. I think the classical Greeks were devoted to a kind of transcendentalism and idealism. But when we think of the Homeric tradition, Hesiod, and so on, that is a pre-ontological, predualistic Greek tradition. In some ways this early Greek tradition resonates more closely with the classical Chinese worldview in the sense that it dramatizes the human experience, and focuses upon the human life. But what happens in the evolution of Greek thought is a break in the tradition where Pythagoras as a "philosopher" is left behind, and from Plato and Aristotle on we turn to philo-episteme. Even though the classical Greek philosophers were doing spiritual exercises, for Plato and Aristotle, the ultimate goal is a kind of theoria that allows us to access what is transcendental. Aristotle of course critiques Plato, but Aristotle is still transcendental in the sense that his concept of form is an immanent form that is unchanging with reference to human experience. As human beings we are formally identical. So both of them are transcendentalists. And then of course the Christian tradition is wholly transcendental, with God being radically other. And God is perfection. The ideal is what is most real. What is most abstract is what is most real. What is most real in us human beings is the immortal soul. And the remaining aspects of the human being are incidental-just changing our clothes. But that's not a Chinese way of thinking at all.

BAI: Earlier you talked about a kind of philosophy that belongs to the everyday, the enactment of which is education. So, this notion of philosophy is what attracted you to Asian Philosophy?

AMES: I have always thought that philosophy ought to owe its allegiance to the real world. That's where we begin together. Social intelligence is our best hope. If we have any kind of optimism as human beings, it has to be that we can develop the social intelligence to leave the kind of Vietnams and Irans and Iraqs-these kinds of conflicts-behind, and learn to live as cultured, civilized, intelligent human beings. For me the Chinese tradition promises us that. What you have in the $20^{\text {th }}$-century Western philosophy is a critique of transcendentalism. When we look at the $20^{\text {th }}$-century Western philosophy-phenomenology, existentialism, postmodernism, post-structuralism, pragmatism, etc., are a revolution against eidos - the claim that there is some kind of foundational and causal notion of God writ large. That being the case, the philosophers who really interest me are the pragmatists because, unlike Heidegger and a lot of the other revolutionaries like the existentialists and so on, whose major contribution is a critique of transcendentalism, pragmatism is an attempt to articulate a philosophy that is an alternative to transcendentalism, and that's where it intersects with Chinese philosophy. So I do a lot of work on Dewey, James, Emerson, and Rorty because I see the pragmatic tradition as having resonances with Chinese philosophy.

BAI: My perception is that, in the East, Western philosophy is very much revered and prioritized, whereas Asian philosophy is marginalized and is not taken seriously. I suppose this is part of the colonial legacy.

AMES: Things are changing. Let's look at the twentieth century. John Dewey goes to Beijing in 1919, three days before the May $4^{\text {th }}$ movement, and he spends twenty-six months there, giving lectures all over the country. At that point in time, the influence of Western philosophy on Chinese philosophy is that Kant should be taken as a gold standard to which Chinese philosophy should aspire. But if you rehearse the relationship between Chinese philosophy and Western philosophy across the twentieth century, you go from Kant to Hegel to Wittgenstein, and now to Heidegger. It really is a transition 
from a philosopher being held as a paradigmatic standard to philosophers who can engage philosophically. There are a lot of ideas in Heidegger that you can use to have a conversation with Chinese philosophy. So Western philosophy goes from being simply a standard setter to an interlocutor, a conversation. My argument would be that the next station after Heidegger is Pragmatism. You can't go to Heidegger for ethics. If metaphysics and epistemology are the centerpieces in Western philosophy, then ethics and aesthetics are the centerpieces in Chinese philosophy. You don't get much of the latter in Heidegger. You get much more of that in Pragmatism. For instance, in Dewey's Art as Experience he celebrates moral imagination as a foundation to achieving moral competence. Dewey goes in his later life to art as the heuristic for human consummation.

So, China has been moving, but the concern that you have raised is really something that has only changed within the last ten or fifteen years. We can make this argument: We can say that up until 1980s, the self-understanding of professional philosophy was that it is Anglo-European philosophy. That it is analytical philosophy and Continental philosophy-heirs to Empiricism and Rationalism, and that indigenous philosophies were left out of this self-understanding. So it doesn't matter if we go to Beijing or to Seoul or to Tokyo or to Delhi or to Nairobi or to Boston: In China, "philosophy" is not Chinese philosophy and in America, "philosophy" is not American philosophy, either. The most important philosopher in China is not Confucius but Heidegger and the phenomenologists. In Delhi the most important philosopher is not Shankara; it is Wittgenstein or Kant-some version of analytic philosophy. If we go to Boston, American philosophy isn't "American" philosophy. American philosophy too was totally marginalized. If you went to a philosophy department in America fifteen, twenty years ago and said you want to do a Ph.D. on John Dewey, they would laugh and say, "Dewey, third-rate philosopher! I think they are still talking about him in Education.” And they would condescend: James, Dewey, and Emerson — these are not philosophers; they're literary figures and psychologists. Not philosophers. But today, a decade or two later, it's quite different: American philosophy has become a major movement within American philosophy.

BAI: So, how has this kind of change of heart in philosophy come about in the last ten or fifteen years?

AMES: When you look to pre-Darwinian Western philosophy, what you see is philosophy grounded in substance ontology. It's all about substance — a reality that stands behind everything. The emphasis upon the individual agent has to do with human "being" grounded in some definition of what it means to be. Soul is another way of saying substance. But in the post-Darwinian West, you have the West trying to get past substance thinking, past ontological thinking, and trying to think process. And so what I anticipate is that we will have an appeal to the kind of process philosophy that we find in the Yijing, Dao De Jing, Zhuangzi, and Lunyu. China has been thinking process for two thousand years. As the West struggles to think process, our best shot has been Whitehead. And Whitehead is really a failed process thinker! Whitehead, on the one hand, wants to talk about process, but on the other hand, he's got eternal objects and the primordial nature of God. There's the big shadow of Aristotle that still remains. Whitehead hasn't gotten there. But the Pragmatists are doing much better. I think Dewey is a much more coherent process thinker than Whitehead ever was.

So what had happened in the relationship between Western and Chinese philosophy was a kind of asymmetry, where Western philosophy was not interested in Asian philosophy, and Asian philosophy was simply taking Western philosophy as its standard. But what has happened more recently is that they have gradually come into conversation with each other, and you thus have an opportunity for mutual enrichment.

BAI: Thank you, Professor Ames, for sharing your thoughts and observations with us. We will be continuing our conversation soon again. 